\title{
THE NEUTRAL PERSPECTIVES \& ITS PRACTICE AMONG THE KOM REM IN MANIPUR (INDIA)
}

\author{
Leivon Jimmy Kom \\ UGC Junior Research Fellow \\ Department of Political Science \\ Manipur University, Canchipur, Imphal-795003.
}

\begin{abstract}
:
The purpose of the paper is to explore the unique and distinctive charisma of the Kom Rem or Koms, who are relatively small group of tribes in Manipur, North East India. The present paper takes into account the six constituent tribes of the Kom Rem and its socio-political constraints during the last decades of ethnic upsurge in the state of Manipur. It extracts the traditional geo-political implications of the tribe's 'neutral approach'; and its peculiar features as a way to lessen ethnic conflicts of bigger tribes vis-a-vis inter-tribal feuds at their nearest geographical suburbs. The paper concludes, the orientations and practices of these tribes during the ethnic conflicts of the 1990s in Manipur were unique conventional practices hardly materialized by any mainstream society. Neutral in nature, it must be conceded that this perspective was developed as results of natural inter linkages of various perceptible traditions and the need for a common principle in defining relations between the Kom Rem tribe, its constituent groups and the other. It was also the result of a long standing and mythically rooted 'collective identity'- the Kom Rem or Koms, which has mismatches the communal advances amongst various belligerents recently.
\end{abstract}

Key words: Kom Rem, ethnicity, neutrality, geo-political tradition.

\section{Socio-Political Study}

Methodology: Historical, descriptive and analytical.

\section{Council for Innovative Research}

Peer Review Research Publishing System

Journal of social Science Research

\author{
Vol.2, No.2 \\ editor@ijssronline.com \\ www.cirworld.com, www.ijssronline.com
}




\section{INTRODUCTION}

The construct of "Neutrality" is a phenomenon characterized by the pursued of an attitude of 'impartiality, nondiscrimination and absence of preference,". More specifically, it is concerned with an attitudinal maintenance explaining the position of a group towards belligerents in a preconditioned environment of conflicts over land or territory, ethnicity or enmity, nationality or races, etc. within or without a state. Truly, the appropriate way to understand this neutrality would be two ways: one, appreciation of the behavioural responses of the neutral group or groups and two, relating this development relatively through the period of upsurge.

As will be seen, ethnic assertions in North East India and elsewhere have now been rendered more or less crucial facet in India's nation building process as these assertions currently give rise to unprecedented conflicts within. And situating neutrality of the Kom Rem as will be discussed later, in principle, which basically denounce intervention or interference could hardly thus, served the purpose of its neutral conception. It, however, becomes the unseen rallying symbol of peace and a hopeful encapsulation for the future of various ethnic groups.

Broadly, Manipur has two distinct topographical units: the valley plains and the hills. Closely based and knitted around this hill-valley topography is the natural pattern of mass distribution. The valley populace has predominantly the Meitei and later Pangals severing liaison from the thirty four recognized tribes comprising the hilly inhabitants. These tribes are dispersed geographically into five hill districts and twenty five sub-divisions more or less in a cluster mode commune.

The clustering hilly topography not only differ from the valley plains, but add to some degree, a set of distinct parameters representing 'hill-valley' cleavage and also at the same level assumed celebrative roles in the formation of various inter ethnic divisions like Kuki- Naga and its conflict paradigms. The implications further extended to construct or propound varied feudal theories or narratives on the origin, migration and antique related events resulting to diverse setting of the ethnic tribes and their contentious historicity on uniqueness.

In this regard, the Khurpui origin, as a concealed identity of the Kom Rem tribes, has an intrinsic element that dominates each kindred tribe through different dialects, generating and reverberating a sense of oneness amidst divisions across cultures, time and space, which in short are anti-feudal. During these last few years of ethnic upsurge in the state, this narrative has been pressurized and questioned owing to untimely and lapsed eroded sense. The sense, only few elderly could retain, as though has appeared to lose its relevance of Khurpui ancestors and their intimate collectivity, still remained embedded in memories and folklores today.

As it has been witnessed, ethnic pressures though tremendous have not questioned their being descendants and offshoots of khurpui or the Khur (meaning the Great Whole or Cave). Instead, a broader perspective of Khurpui narrative or origin has evolved which encompassed not only the Kom Rem tribes but fostered a close narrative with other tribal groups, some belonging to the Kukis and the Nagas of Manipur. Within this theoretical framework, the Kom Rem tribes, as comprehended by the author, possessed one most important 'neutralizing factor' which at work could be successfully developed and employed in bridging the hill-valley divide and the kuki-naga ethnic conflicts. Manipur has a range of fragile events where the communities are arrayed into conflicting or belligerents situation. For analysis, the author will try to deliberate on the above conflicts and also the later, which concerned Kom Rem tribes the most i.e. the Kuki-naga ethnic conflicts.

\subsection{The Kom Rem tribes: Constituting a framework}

The term Kom Rem or Komrem symbolizes a 'collective identity' representing six small tribes in Manipur, one of the most ethnically vibrant states in North East India. It includes the tribes of Aimol, Koireng, Kom, Chiru, Kharam and Purumi. Majority of these tribes lived at the foothills and adjacent valleys while few villages scattered deep inside the hilly terrains of Senapati, Tamenglong and Churachandpur districts of the state and thereby advancing its geo-political construct.

The foothills and adjacent valleys relating to the Kom Rem tribes hinted at the seaming expanse in developing cultural historicity of the state in a manner uniting the initial topographical distinctions. But unlike few conservative tribal groups in the valley, these tribes have been swayed notably by the valley populace which ameliorate to constitute a conceited cultural potency of 'otherness', between the Kukis and the Nagas. It grows to be one rationale object that contextualizes the notion of ethnic non-align expression amongst the tribes of North East India.

Oral folktales suggested that the Kom Rem tribes were a descendant and offshoots of Khurpui ancestors. They have a well established and time honored story of their evolution from a cave or khurpui. This fact was traditionally perceived and culturally shared as the origin of their collective identity. A folksong clearly expressed this collectivity in 'Ami kan hong e, Khurpui a kan hong', which is literally translated as 'we come out, from a cave'.ii

Although the number of constituent tribes of the Kom Rem remains invariable, it appears to have changed from time to time. The 1927 Kom Rem Students' Conference held at Kangpokpi also recorded and mentioned as it were, five constituent tribes within the Kom Rem. They were the Aimol, the Koireng, the Kom, the Chiru and the Purum. Later, it came to be accepted as comprising six tribes tallying the Kharams on the list. This is to be attributed to the recognition of Kharam as a separate tribe in 2002. The total population of these six combined tribes is 27156 souls as on 01.01 .2001 , making about $3.64 \%$ of the total tribal populations in Manipur. ${ }^{\text {iv }}$

Earlier, they were not recognized separately as a tribe even though their existence has long been recorded and acknowledged ${ }^{v}$. Even after this and presently, there are some other groups within the Kom Rem which had been manuscripted earlier by the British ethnographers, their recognition as a separate tribe still waits. They are the Tikkhup, the Lutar, the Muntak and the Hmongtung or Mongdung, all the listed communities are further sub-divisions of the Koms 
tribe (R.Brown, 1874:53). Once the recognition becomes effective as separate tribes, the number of the constituent units will also obviously increase.

At present, the Kom Rem people are found concentrated particularly in Chandel and Churachandpur districts and along the western hills of Manipur chiefly in Senapati \& Sadar Hills.

\subsection{Ethnic conflicts in Manipur: Viewing from the Kom Rem perspectives}

Manipur has in total thirty four different recognized tribes as maintained by the latest the Constitution (Scheduled Tribes) Order (Amendment) Act, 2011. These tribes by and large are assembled into two major groups- the Kukis and the Nagas. Excluding the valley Meitei and the pangal, the entire socio-political issues and problems of the hills in Manipur accrued around these two ethnic camps. Since the last two decades, Manipur has been infested with various forms of sociopolitical issues rooted in ethnic conflicts leading to insurgent movements on ethnic lines, confrontations of civil societies belonging to various ethnic groups, ethnic based electoral politics and participations, creation of ethnic-centric vote banks and the recent clashes over the Greater Nagalim or Supra State of the Nagas on the one hand and the Zalengam or Kuki state on the other vis-à-vis the integrity of Manipur.

The Kom Rem tribes have displayed a peculiar characteristic of minimizing conflicting areas toward the sociopolitical issues of the state in the past. In trying to assess this reality, it becomes central to recognize the tribes' response or the approach adopted by the Kom Rem tribes, to the last two decades of ethnic upsurge within the state.

The genesis of the Kuki-Naga imbroglio began since early of 1992. The bone of contention was the control over the Moreh Township and its commercial viability. In the beginning, the clash was selective i.e. between the Thadou kukis and the Maring nagas but later; it became the spring source of feudal obligations amongst the various tribes and subtribes of both the Kukis and nagas in Manipur. The clash cemented into what is now commonly understood as Kuki-Naga conflicts encasing over a wide range of interests. Though economic reasons were the primary source, it now simulates into two water tight compartments of diverging views.

The Kom Rem tribes' first and foremost response during the Kuki-naga ethnic conflict was its co-existence stance with regard to the then ethnic clash ${ }^{\mathrm{vi}}$. A neutral approach was adopted with a view to embrace an 'impartial attitude' towards all belligerents. The implication of the decision was 'not to show discrimination or preference' towards any groups and, therefore, offered no feudal obligations in determining its positions. The Kom Rem Baptist Churches Association (KRBCA), as their apex religious body, took the initiative of spreading the message of love, peace and brotherhood, which in short are anti-ethnic conflicts. vii

Secondly, the growth of insurgent groups aimed at 'ethnic-nation-land' conjectures in Manipur is one of the greatest setbacks in India and represents 'War inside a War' phenomenon. To quote Ms. Binalakshmi Nepram,

"There is the emergence of a new phenomenon in Manipur and other parts of North East India and I call it the 'War inside a War' phenomenon. War was waged against the Government of India but now there are conflicts within the various communities and tribes. For instance, of the hill tribes, the Nagas and the Kukis form a major proportion"viii.

The Kom Rem society which shows no sign of the presence of insurgent group(s) until the last decade of the 20th century were urged, as it appears, to follow the trend since the later part of the first decade of the 21st century. This could be witnessed from the emergence of four insurgent groups which has been brought to light. They are the United Komrem Revolutionary Army (UKRA), the Komrem People's Army (KRPA, also known as Kom Rem People's Convention or KRPC), the Kom Rem Region (KRR) of NSCN-IM and, the Manipur Komrem Revolutionary Front (MKRF). It is unanimously held that, the first three groups are multipart of the Kukis, the valley hubs and the Nagas, respectively ${ }^{\text {ix }}$. MKRF, on the other hand has appeared only on few occasions in public domain. ${ }^{x}$

The existence of visiting or ceremonial type civil society groups among the tribes has lessened its obligation and roles in the ethnic pack of cards. Unlike the unions and associations of other ethnic communities having the potential to impose strong agitations such as economic blockades, bandhs and general strikes, the civil society groups of Kom Rem are anemic. Civil society groups among the Kom Rem include the KRBCA, the KRSUM (the Kom Rem Students Union Manipur), the Kom Rem Union (A political union of the tribes with no record of electoral participations), the KRCWA (Kom Rem Chiefs Welfare Association), and KRDO (Kom Rem Development Organization which is defunct now). Interestingly, each constituent tribe has each own civil society organizations, churches, students' associations, youth organizations, etc. to cater and fulfilled the needs of each Kom Rem groups ${ }^{\text {xi }}$

\section{EXPLORING THE KOM REM'S PERSPECTIVES: NEUTRALITY OF MYTH AND ITS REALITY}

Most tribal groups in Manipur have propounded-'oral traditions' handed down from their forefathers as the only surviving source of their existence. Traditional life is in the form of mythical illusions as these oral traditions often deals with imageries of animals, birds and insects wonderfully woven as a part of the story. This has made the theory dealing with the past's life of tribal groups both mythical and illusive.

Various aspects of the origin of tribal groups agreed, as such, with a myth that says, "Life on earth was a divine creation; man and woman were created by god out of clay from the earth. In their march for survival from potential enemies the men and women in their believed cultural attires took shelters in a cave". And from this cave sprang out folktales which could be marked as the origin of indigenous tribal groups in Manipur. These indigenous tribal groups include among others, the Aimol, the Anal, the Chiru, the Chothe, the Gangte, the Hmar, the Kabui Naga, the Kacha Naga, the Koirao or Thangal, the Koireng, the Kom, the Lamgang, the Mao, the Maram, the Maring, the Monsang, the Moyon, the Paite, the Tangkhul, the Tarao, the Thadou, the Vaiphei and the Zou. 
The Kom Rem tribes or the Koms which includes the Aimol, the Chiru, the Kharam, the Koireng, the Kom and the Purum tribes adhered to this mythical narrative in exploring inter-ethnical relationships and obligations. Viewed from this perspective, similarities in oral traditions in general and the uniqueness of the Khur or Cave narrative in particular, could immensely narrow down the divergent views of the belligerent tribes as mentioned earlier. The founding of the Khurmi National Union ${ }^{\mathrm{xii}}$ was an indicative of how the Khur or Cave narrative could rope the various tribes into one podium due to be belligerent by then. However, its quick deadening provided a space for divisive ethno-centric elements which became fatally visible since early 1990 s.

Of course, it has to be noted here that certain elements with regard to spots, locations, etc. of the cave might stil be exasperation, but otherwise, is simply directional to the Koms or the Kom Rem. It is generally understood the Nagas represent communities of the northern region of the state and Kukis, the south. This has also become reasonably speculative towards the Kom Rem society with three of the four insurgent groups multiparty to larger ethnic communities.

Again, the interplay of linguistic classification and ethnic affiliation of the tribes towards larger communities in Manipur has a virtual role in comprehending the neutral perspectives. The earliest interesting and peculiar observable facts about the subject of interests of these tribes were recorded in the works of R. Brown's Statistical Account of the Native State of Manipur and the Hill Territory Under its Rule (1873), Alexander Mackenzie's History of the Relations of the Government with the Hill Tribes of the North East Frontier of Bengal (1884), Sir James Jonestones' My experiences in Manipur and Naga Hills (1896) G.A Grierson's Linguistic Survey of India, part III of Volume III of the Book, TC Hudson's The Naga tribes of Manipur (1911) and J. Shakespear's The Lushei-Kuki Clans(1912). However, it was the work of Grierson on the linguistic affiliation well elucidated in his series of voluminous Linguistic Survey of India. He classified his 'Tibeto Burman' speakers in Manipur into four sub-groups: Naga-Bodo, Naga-Kuki, Northern Chin and the Old-Kuki. The Naga-Bodo sub groups consisted of Kacha Naga, Kabui Naga and Koirao; the Naga-Kuki consisted of Mao, Tangkhul and Maring; the Northern Chin consisted of Thado, Paite(Zou, Vaiphei), Ralte and Simte; and, the Old-Kuki sub-group is mainly comprised by Aimol, Chiru, Koireng, Kom, Hmar, Purum, Anal, Hiroi-Lamgang (Moyon, Monsang, Lamgang) tribes.

Grierson's classification was in and out linguist driven irrespective of communal or political affiliations. This was re-affirmed by J. Shakespeare when he dealt with the later Old-Kuki sub groups in his 'The Lushei-Kuki Clans' in 1912.

“...but Dr. Grierson in the Linguistic Survey has included a number of clans which had long been settled in Manipur territory, and my enquiries all go to prove the correctness of this classification."

However, the most dismal part occurred when the ethnic upsurge in the state overcast this traditional linguistic affiliation with ethnic, communal and political contempt. This contempt put majority of the tribes into two camps, the Kuki \& Nagathe belligerents of the 1990's ethnic conflict in the state. What remains not ostensibly vague is that, all tribes, sub-groups and their clans have been superficially classified into two camps- the Kuki \& Naga or, the aspirations which still continue in the form of the two belligerent states -Zalengam \& Nagalim.

Ethnologist might refer to it as typical polarization, which on the other side, appeared as a vivid picture of feudal obligation of smaller tribes into the domain of bigger groups. And in this real phenomenon of ethnic rivalries, if it be ethnic polarization, it occurred consistently near the overlapped region where the smaller and the lesser Old-Kuki sub groups bordered the other but larger linguistic sub-groups.

The Kom Rem tribes which form majority of Grierson's old-Kuki sub groups, overlapped with recent ethnic assertion that these tribes are either Nagas or Kukis. Furthermore, of the eight tribes of the Old-Kuki sub group, three tribes- the Mhar, Anal and Hiroi Lamgang are evidently part of the ethnic fervent. The five remaining tribes of Grierson's old-Kuki sub groups, on the other hand, cemented their stance into the Kom Rem. A closer look on these tribes and 'the Kom Rem formation' revealed the interplay of theoretical contradictions between the old-linguistic based classification and the recent communal based ethnic affiliations. The synthesis of contradictions that often leads to a series of fundamental questions on as to which side (either Nagas or Kukis) these tribes fit in. This led to lesser recognition of their existence, groupings and aspirations in public eyes but in reality, the perspective of co-existence in overwhelming situations.

\subsection{Understanding the Kom Rem 'Neutral Perspectives' from its geo-political tradition}

The tribes of the Kom Rem shared unfathomable bonds within the Koms or the Kom Rem nomenclature as well as with their nighbouring tribes. They lived in the Southern parts of the state and more so remain scattered around the valley ${ }^{\text {xiii }}$. In turn, they were identified collectively as the Koms and also by their synonymous names- the Koirengs, the Aimols, Chirus, Kharams, Purums, etc. together implicit as 'Turban tribes (known as Lukom or Lukim among the Koms and Luhup ${ }^{\mathrm{xiv}}$ to the Moirangs) of Moirang, Suknu, Langhmeitong and south-western hills (The Thangjing Hills) of Manipur valley and along the foothills in the royal chronicles of Manipur ${ }^{\mathrm{xv}}$ and other literatures of the Moirang Kangleirol. 
To understand the characteristics and nature of this perspective associated with the Kom Rem tribes, one should acknowledge and savor the inter-play of various elements (both mythical and historical) giving an in-depth honour to its geo-political evolution and diffusion.

\subsubsection{Geo-political evolution}

The evolution of the Kom Rem people and its mythical past has an influencing role in shaping its geo-political tradition. In regard to this two different diametrically opposite theories on the evolution of Kom Rem tribes are worth noting.

One theory associates the origin of the Kharams (a sub-division of the Koms) to mythical place or site at Makhel which is supposed to be the present Makhel Village in Mao-Maram subdivision of Senapati District, and a cave Khurpui somewhere nearby during the Stone Age. ${ }^{\mathrm{xvi}}$ This un-ascertained theory drifted the gravity of the Koms, therefore, towards the extreme North of the state (Compare R. Brown, 1873: 53 \& Dhiren W., 2007:7) ${ }^{\text {xvii }}$.

Quite opposite to the above theory runs the generally perceived cave-Khurpui, also referred to as Chhinlung, Hurpi, Khol, Khul or Khur by scholars of the Koki-Chin-Mizo group. It may also be noted that in spite of the different names used, scholars of Kuki Research Forum agree that these different names refer to the same place or site of the Songbuh, Phoikon Haosapi and the Senlung caves in South West Chandel District near Indo-Myanmar border. In fact this leads to the tendency to bring the Kom Rem people within the fold of the kuki-Chin-Mizo group of tribes.

In fact, unnoticed tribal movements did occur within Manipur when sometimes out in the open even shown them as migration hordes. It was very difficult to distinguish between this type of tribal movement; uttered immigration and emigration as the national boundary is just sixty six years old. The distribution of populations, settlement areas and sites reflect changes from time to time although altered very little in patterns if not for political reasons.

The anomalous North-South findings of the above two theories put the Khurpui narrative of the Kom Rem tribes at cross-roads, greatly at stake. However, oral traditions still persisted and adamant to a propos the evolution of the KomRem as originating from a mystic 'Khurpui' which not only represent the name of their enlarged group but also the sum total attributes of 'beliefs, attitudes and characters' as traditional aspects' of the most indigenous tribes in Manipur- Aimol, Koireng, Kom, Chiru, Kharam and Purum. The beliefs in brotherhood, neutral attitudes, and co-existence characters are manifested traditions of the Khurpui tribes- the Koms or the Kom Rem.

\subsubsection{Geo-political diffusion}

About the same time, the places of settlements were mainly on the outskirts of Moirang at Ngairong, Sakang khangyan $^{\text {xviii }}$ (present sagang), Suknu ${ }^{\text {xix }}$, Tonsen $^{\mathrm{xx}}$ and widely scattered in the surrounding foothills of the valley.

The Aimol who parted their ways aftermath the Sukte invasion on the the Kom Rem tribes are found to distribute thinly in fifteen villages across the state at present mostly in pallel areas of Chandel district in the state. The Koirengs resided mainly in the Sadar hills in nine villages (Litan in Chandel belongs to Lutar group of the Koms); the kom in forty seven villages most of which were recently established from few old villages; the Chirus in thirteen hamlets mostly concentrating in Senapati villages and at Waithou and Uran; the Kharams in five, mainly at Kharam pallel and Phaizol; and the Purums in two hamlets-Purum Khullen and Purum Likli. ${ }^{x x i}$ These tribes at present known by the name Kom Rem unevenly scattered around the valley and the surrounding hills in eighty seven thinly populated hamlets across six districts of the state comprising only $3.96 \%$ of villages in Manipur ${ }^{x \times i i}$.

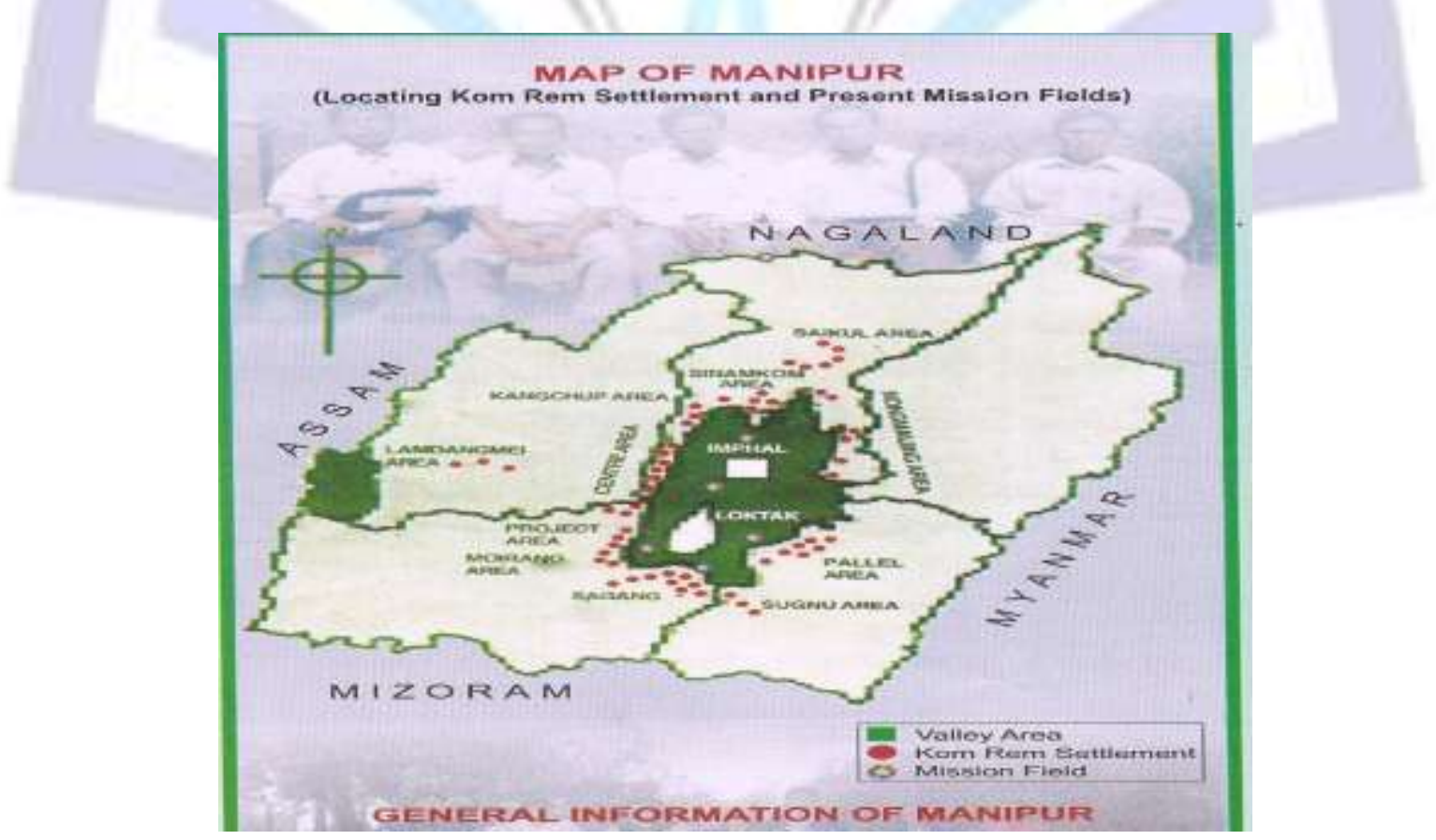


Figure. Map of Manipur showing the Kom Rem villages in red dots (Excerpts from ' 50 years of KRBCA and ahead' issued and published by Mission Department KRBCA)

The population of these tribes as on $01.01 .2001^{\text {xxiii }}$ is

$\begin{array}{lc}\text { Tribes } & \text { Total Population } \\ \text { Aimol } & 3643 \\ \text { Chiru } & 5487 \\ \text { Kharam } & 1000 \\ \text { Koireng } & 1056 \\ \text { Kom } & 15467 \\ \text { Purum } & 503 \\ \text { Total } & \mathbf{2 7 1 5 6}\end{array}$

The voters compiled for these tribes as on 01.01 .2012 on the eve of the 2012 State Assembly election ${ }^{\text {xxiv }}$ in the state is:

$\begin{array}{lrrr}\text { Tribes } & \text { Male Voters } & \text { Female Voters } & \text { Total Voters } \\ \text { Aimol } & 1065 & 1128 & 2193 \\ \text { Chiru } & 2320 & 2387 & 4704 \\ \text { Kharam } & 351 & 362 & 713 \\ \text { Koireng } & 594 & 651 & 1245 \\ \text { Kom } & 4546 & 4957 & 9503 \\ \text { Purum } & 140 & 157 & 297 \\ \text { Total } & 9016 & 9660 & \mathbf{1 8 6 7 6}\end{array}$

Disproportional to their diminutive figures in population and number of voters, the Kom Rem are politically, distributed in eleven Assembly Constituencies across the hills and the valleys of Manipur. Of the total eighty eight villages, seven belong to the four valleys' Assembly constituencies (A/C Nos.6-Keirao, 8-Lamlai, 9-Thangmeiband and 36-Wabagai) in general categories, and seventy seven belonging to seven hills' Assembly Constituencies (A/C Nos.41-Chandel, 42Tengnoupal, 46-Saikul, 51-Saitu, 54-Nungba, 57-Henglep and 59-Saikot).

This scattering political residences at first appeared as settlement aspects which attributed to development of phantamagoristic phenomenon among the Kom Rem tribes- a midst a contesting gravity of power polarity (perceived as bi-polar forces of the Kukis and Nagas). Such geo-politically motivated aspects breed a fear psychosis to willfully participate in state politics and the like. However, these issues were an embedded inside story of their existence with separate identity-the Kom Rem who are geo-politically situated for the purpose. This fear psychosis, according to James Scott amongst others included slavery, conscription, taxes, corvee labour, epidemics and warfare ${ }^{\mathrm{x} v}$ which have assumed a totally different aspect in ethnic-conflicts ridden states like Manipur.

\subsubsection{Constraints on the Neutral Perspectives:}

Taking account of their population some of whom were negligible and very small, threats and other forceful measures were issued to these tribes. For instance, Dr. H.Kamkhenthang mentioned a stand-off between the KNO and the Koms where the later were threatened with abusive words such as"... and you Aimol, Kom people would stand alone and at that time, we KNA can bring the CHIN Hills force at any moment and finish you all....the four corner of the state belong to us, the Kipgen Kukis and that we have every right to do anything as we like now and it is a mistake for people like you to neglect by not joining our party whereas we the leaders are all state officials in all circles..."

These tribes who have been living together peacefully, independent of outside forces or colonial powers since time immemorial have to bear the grunt of such outrageous. The six tribes as mentioned earlier, do not have a common political platform earlier, instead they were identified by their name or village or places which bears insignificant characters to their common origin. However, they were able to protect their groupings and lived together until internecine fights broke out to separate them. They were small in numbers but indeed very powerful. The Kharams for example, fought battle with the erstwhile Manipuri king in 1779. xxvii This independent existence of the Kom Rem tribes who are relatively lesser to their fellow hills men posed a great challenge to the nationalist spirit filled Nagas and Kukis since the end of the colonial era. The Kom Rem people became geo-politically conscious as neighboring tribes began to group into the Naga and Kuki folds. This consciousness leads them to choose the path of neutrality in answering the ethnic assertions in the state.

By all accounts, the bipolar forces in the hills ruled supreme and their guns dominated action. The Kom Rem community living in distant and scattered villages both the hills and the valley suffered from potential threats: illegal immigration, ethnic polarization, ethnic violence and security threats to life and property. Again, the population growth of the majority tribes in Manipur is one of the highest in India. Comparatively, the population of the Kom Rem tribes has dwindled to a modest than its original strength. Their political participation and opportunities faced a bleak future and almost shrank to zero when elections were contested on communal ground, a very commonplace on the eve of elections in the state. ${ }^{x x v i i i}$

\section{Conclusion}

The perspectives unabatedly have a Khurpui narrative divulged from what was precedential antiquity, extending to a broader dimension of the Kom Rem tribes- beliefs, attitudes and characters as its traditional aspect. These changes 
combined with radical transmutation perceived from within each constituent tribes of the Kom Rem has contributed more or less against their ethnic contempt.

The perspectives also allow each side of the ethnic assertive debates to stress its own ideological interpretation, not in a way offensive to the other(s) by acknowledging the socio-political cleavage. However, the perspective was committed to upholding neutrality as the basis. As such, the Kom Rem perspective of neutrality has assumed to be coexistensive encompassing enough rooms for the belligerent ethnic tribes.

The intimate linkage of ethnical roots, social beliefs and practices is again so compatible to the neutral approach that one could assert for the existence of common cultural experience; the time frame of which could aptly be not a matter of few years unless loosely connected and partially bonded from different ethnical grounds. Inferences derived from the records and memoirs of the Kom Rem elders especially the Christian theologians who were the first educated stock amongst these tribes possessed one note worthy piece staging a common ground of social and cultural unity which can't simply be ignored. Christianity has already reached the Kom Rem tribe's three decades earlier 1947, and so independent India simply paved the way for their faster assimilation to the biblical belief in love, respect and brotherhood which became the backbone of the Kom Rem perspectives. As such, in the new era of evolving ideological outlook and differing views, the perspectives is a whistling blow in narrowing the gap and sensitive differences in beliefs and values of every stakeholder in the ethnic conflicts of the state.

\section{Notes \& References}

i. See the New Illustrated Columbia Encyclopedia, Vol. 16, Rockville House Publishers, Garden City, N.Y. 11530, Columbia University Press, New York.

In this paper, the words (concept of neutrality) are summarized to three important key words: impartiality, non-discrimination and absence of preference.

ii. R. Brown mentioned these tribes as sub-divisions of the Koms in his 'Statistical Account of the Native State of Manipur and the Hill Territory Under its Rule (1874:53)'. Alex Akhup, in an article 'The Lived Reality of Koms (Komrem) in Manipur: An Emerging Political Perspective' to the Journal of North East India Studies,Vol. 2, No. 2, Jul.-Dec. 2012, pp. 1-12 referred these tribes as Komrem. Whereas the term 'Kom Rem' is used by the apex religious body of the six tribes- Kom Rem Baptist Churches Association or KRBCA. Also refer to Benjamin Kom's the Kom Rem People (1990).

iii. This mythical event of tracing origins of tribe is also shared by twenty three tribes in the state of Manipur. However, the Kom Rem could be segregated from the rests on the basis of the cave's name khurpui, used by these groups. The original folk song runs in one stanza (eight lines) as "Ami Kan hong e: Khurpui a kan hong..." See Benjamin Kom's the Kom Rem People (1990:10).

iv. According to 2001 Census, the total populations of Manipur was 21, 66,791 and the tribal constitute about $34.41 \%$.

v. The presence of constituent tribes such as the Kharam, the Aimol, the Chiru and the Koms had scores of skirmishes with the Meitei kings; the counters and encounters were well recorded in the Cheitharol Kumbaba, the Royal Chronicles of Manipur (Saroj Nalini Arambam Parratt translated version).

vi. See Alex Akhup; notes and references.

vii. At the celebration of its fifty years of existence, the KRBCA published pamphlets where in its 'Vision \& Mission' reads as "Understanding location of our settlement in the overall geographical map of Manipur, we have now realized that though few and insignificant we are, God has chosen us to serve Him in Manipur in 3 fronts: to bear and preach the love of God specially to our valley brothers of Manipur and then to the people of South East Asia; to encourage and strengthen the churches; and, to promote and enhance love and peace amongst all brothers of Manipur".

viii. Binalakshmi Nepram, South Asia's Fractured Frontier: Armed Conflict, Narcotics and Small Arms Proliferation in India's North East, Mittal Publications, New Delhi (First Edition, 2002) p.77

ix. $\quad$ Ngamkhohao Haokip and Michael Lunminthang (ed.) The Kuki Society: Past, Present and Future, Maxford Books, New Delhi; p.238

x. MKRF appeared all of a sudden only at the time of assassination of Mary Kom's in law on 29 $29^{\text {th }}$ Dec. 2006; also at the arrest of one of its cadre on $22^{\text {nd }}$ Feb. 2008.

xi. Refer to Alex Akhup.

xii. The Khurmi National Union (KNU) members included among others, members from different communitiesThadou Kuki, Tangkhul and the like. These communities have now grouped into the Naga and Kuki ethnic camps.

xiii. Dhiren Singh W, The Kharams in Manipur: An Ethnographic Study, Unpublished Thesis, Department of History, Manipur University, 2007.

xiv. One has to be cautious that, Luhuppa or Luppa tribes, in general referred to the more savaged of the Tongkhuls, who inhabited the hills to the north and east, farthest removed from the Manipur valley. Indeed, the term 'Luhup' is a Manipuri word meaning a hat or a head covering or helmet or a cap like structure and therefore the name 'Luhuppa' refer to those tribes who use 'Luhup'. Luhup is of two types: i. a conical cap like decorative and complicated head dress which belonged only to the Tongkhuls, and ii. a turban or pugri 
wound around the temples and back of the head leaving the crown of the head bare; used exclusively by the Koms, Koirengs and the Aimols.

However, both the varieties of Luhups seemed to have no equivalent name among the northern Tongkhuls, but the southern Luhuppas called the Luhup as Lukim or lukom from which had developed the name of the tribe- Koms. The remaining tribes of the group: Aimol, Chiru, Koireng, Purum and Kharam tribes were evidently considered as the sub-divisions of the Koms.( See R. Brown, 1975:53)

xv. Saroj Nalini Arambam Parratt, The Court Chronicle of the Kings of Manipur-Cheitharon Kumpapa, Vol.2, 1764-1843 CE, Original text, translation and notes, Foundation Books Delhi; p.34.

xvi. Dhiren Singh W, The Kharams in Manipur: An Ethnographic Study, Unpublished Thesis, Department of History, Manipur University, 2007.p7.

xvii. Ibid.

xviii. Ibid, p.12

xix. Saroj Nalini Arambam Parratt, The Court Chronicle of the Kings of Manipur-Cheitharon Kumpapa, Vol.2, 1764-1843 CE, Original text, translation and notes, Foundation Books Delhi, p.3.

xx. Ibid

xxi. Only the inhabitants of these two villages are considered belonging to the Purum tribe in Manipur.

xxii. The total number of villages in Manipur was recorded as 2199 in 2001 (See PL Sanjeev Reddy and PC Shekar Reddy's Peace and Development in North East-A Virtuous Spiral, Mittal Publications, New Delhi, 2002; p.29.

i. Census of India 2001, Manipur, Provisional population total paper -1 or 2. Directorate of Census Operation, Govt. of Manipur, p. 13.

ii. This report is based on the researcher findings of the Kom Rem areas in Manipur using the electoral rolls published by the Chief Election Officer, Manipur prior to the January State Assembly Election, 2012.

iii. James C.Scott, 2009; The art of not being governed: an anarchist history of upland Southeast Asia, New Heaven,CT:Yale University Press,p.ix as quoted by Jean Michaudi his 'Editorial- Zomia and beyond' in Journal of Global History (2010),pp.209.

iv. Refer to Ngamkhohao Haokip and Michael Lunminthang (ed.) The Kuki Society: Past, Present and Future, P. 8-9.

v. Saroj Nalini Arambam Parratt, The Court Chronicle of the Kings of Manipur-Cheitharon Kumpapa, Vol.2, 1764-1843 CE, Original text, translation and notes, Foundation Books Delhi.p.12.

vi. The highest voters recorded among this tribe is at Sagang whose political participation were denied by one of the major communities, see 'The Hindu' dated $6^{\text {th }}$ June, 2010.

\section{BIOGRAPHY:}

Leivon Jimmy Kom, 26, is currently doing his $\mathrm{PhD}$ in the Department of Political Science, Manipur University as UGC Research Fellow. His area of interest includes among others ethnicity, conflict resolution, socio-political studies of tribes and electoral participations.

Photo:

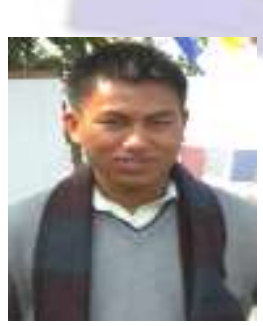

